Selected papers from the International Scientific and Practical Conference "Basic Science for Practical Medicine - 2021", 15-18 September 2021, Elbrus v., Russia, http://uniid.kbsu.ru/medicine2021

Original article

\title{
Stimulation of neutrophil oxidative burst by calcium phosphate particles with adsorbed mucin
}

\author{
Elena V. Mikhalchik ${ }^{1}$, Olga P. Boychenko ${ }^{1,2}$, Alexander P. Moskalets ${ }^{1}$, Olga V. Morozova ${ }^{1,3}$, Dmitry V. Klinov ${ }^{1}$, \\ Liliya Yu. Basyreva ${ }^{1}$, Sergey A. Gusev ${ }^{1}$, Oleg M. Panasenko ${ }^{1}$, Lyubov Yu Filatova ${ }^{2}$, Nadezhda G. Balabushevich ${ }^{2}$ \\ ${ }^{1}$ Federal Research Clinical Center of Physical-chemical Medicine, Moscow, Russia \\ ${ }^{2}$ Lomonosov Moscow State University, Moscow, Russia \\ ${ }^{3}$ National Research Center of Epidemiology and Microbiology of N.F. Gamaleya, Moscow, Russia
}

Received 1 October 2021, Revised 15 November 2021, Accepted 30 November 2021

C 2021, Russian Open Medical Journal

\begin{abstract}
Objective - Mucin can promote formation of gallstones via precipitation with calcium phosphate. The proinflammatory effect of mucin-coated particles is still unclear, and our aim was to study the role of mucin sorption in activation of neutrophil respiratory burst. Material and Methods - Polydisperse calcium phosphate nanowires (CP) were prepared from hot gelatin solution and according to scanning electron microscopy (SEM) had the length 1-10 $\mu \mathrm{m}$ and thickness $50-450 \mathrm{~nm}$. CP were incubated in mucin or human serum albumin (HSA) giving CP-Muc and CP-HSA. Their hemolytic activity towards human erythrocytes was assayed, and neutrophil lucigenin- and luminol- chemiluminescence (LuC-CL and Lum-CL) response to CP, CP-HSA and CP-Muc was measured. Cytokine RNA was detected in neutrophils by means of reverse transcription with subsequent real-time PCR. Cytokines (IL-1 $\beta, \mathrm{IL}-6, \mathrm{IL}-8$, IL-10) were assessed in cell medium by ELISA.

Results and Conclusion - Hemolytic activity of CP was $3.0 \pm 0.5 \%$, mucin sorption $(0.019 \mathrm{mg} / \mathrm{mg}$ ) reduced it to $0.24 \pm 0.04 \%$ ( $<<0.05)$ as well as HSA. CP and CP-HSA stimulated neutrophil Lum-CL and Luc-Cl by 2-3 times vs. spontaneous values while for CP-Muc the effect was $10-$ fold and higher. No increased cytokine gene expression or cytokine secretion was detected after $1 \mathrm{~h}$ incubation of neutrophils with samples. Obviously, sorption of mucin but not that of HSA stimulated generation of reactive oxygen and halogen species with no increase in cytokine production. Thus, the mucin-coated CP has the potential to contribute to gallstone-associated cholecystitis via oxidative damage of mucosa and epithelium.
\end{abstract}

Keywords: calcium phosphate, mucin, neutrophils, chemiluminescence.

Cite as Mikhalchik EV, Boychenko OP, Moskalets AP, Morozova OV, Klinov DV, Basyreva LYu, Gusev SA, Panasenko OM, Filatova LYu, Balabushevich NG. Stimulation of neutrophil oxidative burst by calcium phosphate particles with adsorbed mucin. Russian Open Medical Journal $2021 ; 10:$ e0428.

Correspondence to Elena V. Mikhalchik. Address: 1a Malaya Pirogovskaya St., Moscow 119435, Russia. Phone: +74992464352. E-mail: lemik2007@yandex.ru.

\section{Introduction}

Exogenous nano- and microparticles of calcium phosphate can be inhaled by people, ingested with food additives or toothpaste [1] while co-precipitation of $\mathrm{Ca}^{2+}$ and $\mathrm{PO}_{4}{ }^{3+}$ in the small intestine [2] or gallbladder [3] are considered as sources of endogenous particles. Mucin, a major component of mucosa, is not only absorbed by these particles but is also actively incorporated $[2,4]$. Mucins are high molecular-weight glycoproteins (120-1000 kDa) with sialylated oligosaccharides. Adsorption of mucin by hydroxyapatite is related mainly to Ca-dependent electrostatic interactions between calcium ions and COO- of mucin [5]. The possible role of inflammatory neutrophil-derived factors in gallstone pathogenesis, including reactive oxygen and NETs, is extensively studied [6]. Earlier it was shown that crystals coated with plasma proteins can stimulate greater chemiluminescent response of polymorphonuclear leukocytes than untreated particles [7], but little is known about effects of adsorbed mucin. Mucin is considered rather as a coating preventing excessive activation of neutrophils induced by bacteria [8] or polymer surfaces [9]. It can scavenge hydroxyl radicals, which are formed in respiratory burst of neutrophils [10]. The aim of the present work was to investigate the chemiluminescence $(\mathrm{CL})$ of neutrophils activated with calcium phosphate particles coated with mucin. We also assessed cytokine RNA expression and their secretion by neutrophils incubated with the particles. Polydisperse calcium phosphate nanowires (CP) were studied as calcium phosphate nano- and microparticles varying in the length and thickness. Both lucigenin and luminol were used to amplify neutrophil $\mathrm{CL}$ via reaction with superoxide anion-radical and hypochlorite, correspondingly, as respiratory burst products. Hemolytic activity was also assayed to control possibility of direct cell membrane damage $[11,12]$. 


\section{Material and Methods}

\section{Synthesis of polydisperse calcium phosphate nanowires (CP)}

$\mathrm{CP}$ were synthesized according to slightly modified procedure described in the literature [13]. Briefly, $5.98 \mathrm{~g} \mathrm{CaCl}_{2} \cdot 2 \mathrm{H}_{2} \mathrm{O}$ (EP grade) and $4.8 \mathrm{~g}$ urea (USP grade) were dissolved in water solution $(1.9 \mathrm{~L})$ of gelatin $(1 \mathrm{gL})$ at $80^{\circ} \mathrm{C}$. Then a water solution $(100 \mathrm{~mL})$ of $6.24 \mathrm{~g} \mathrm{NaH}_{2} \mathrm{PO}_{4} \cdot 2 \mathrm{H}_{2} \mathrm{O}$ (purum) was added dropwise within an hour and obtained mixture was gently refluxed for 3 days. Finally, the precipitate was centrifuged, washed twice with isopropyl alcohol (IPA) and vacuum desiccated at $60^{\circ} \mathrm{C}$.

\section{SEM}

CP powder was sonicated in isopropyl alcohol for $10 \mathrm{~min}$, deposited on clean Si-wafer and examined with a Zeiss Merlin microscope equipped with Gemini II Electron Optics (Zeiss, Oberkochen, Germany). SEM imaging was performed at 1-5 kV accelerating voltage and $100-300 \mathrm{pA}$ probe current.

\section{$\zeta$-potential measurement}

The $\zeta$-potential of the particles and mucin was measured using Zetasizer (Nano ZS, Malvern, UK) and estimated using Smoluchowski's equation.

\section{Sorption of mucin and human serum albumin (HSA) by CP}

Mucin from porcine stomach (Sigma) or HSA (Sigma) were thoroughly dissolved in $0.15 \mathrm{M} \mathrm{NaCl}$. CP was suspended in $0.15 \mathrm{M}$ $\mathrm{NaCl}(20 \mathrm{mg} / \mathrm{mL})$ and mixed with equal volume of protein solution $(20 \mathrm{mg} / \mathrm{mL})$, incubated at $37^{\circ} \mathrm{C}$ for $30 \mathrm{~min}$ under vortexing. The control samples were mixed with $0.15 \mathrm{M} \mathrm{NaCl}$ instead of protein solution. Then the $\mathrm{CP}, \mathrm{CP}$ with sorbed mucin (CP-Muc) or with sorbed albumin (CP-HSA) were separated by centrifugation and the supernatants were further analyzed for protein sorption evaluation. The pellets were washed twice with $0.15 \mathrm{M} \mathrm{NaCl}$ and then resuspended in sterile saline.

\section{Protein sorption evaluation}

The unbound portion of protein was assayed in supernatants by absorbance at $214 \mathrm{~nm}$ and by analytical size exclusion chromatography in the Biofox 17 SEC $8 \times 300 \mathrm{~mm}$ column (Bio-Works, Uppsala, Sweden) in a solution of $0.15 \mathrm{M} \mathrm{NaCl}$ [14]. Smartline chromatographic system (Knauer, Berlin, Germany) has been used. Preliminarily, the column was calibrated using solutions of purified mucin with different concentrations $\left(0.01-1.00 \mathrm{mg} \mathrm{mL}^{-1}\right)$. A total of $0.02 \mathrm{~mL}$ of the mucin solution were used for the chromatography analysis at the elution rate of $0.5 \mathrm{~mL} \mathrm{~min}{ }^{-1}$. Absorbance of the eluted solutions was measured using the UV detector at wavelengths 214 $\mathrm{nm}$ and $260 \mathrm{~nm}$.

\section{Blood cells isolation}

Human erythrocytes and neutrophils were isolated from normal blood of 4 volunteers, on the basis of their informed consent. Erythrocytes were sedimented by centrifugation of each blood collected with EDTA as anticoagulant, at 400g and then washed with $0.15 \mathrm{M} \mathrm{NaCl}$. Another blood volume was layered over the double gradient of Histopaque 1.077/1.119 gL and after centrifugation for $45 \mathrm{~min}$ neutrophils were collected and washed with Krebs-Ringer solution.

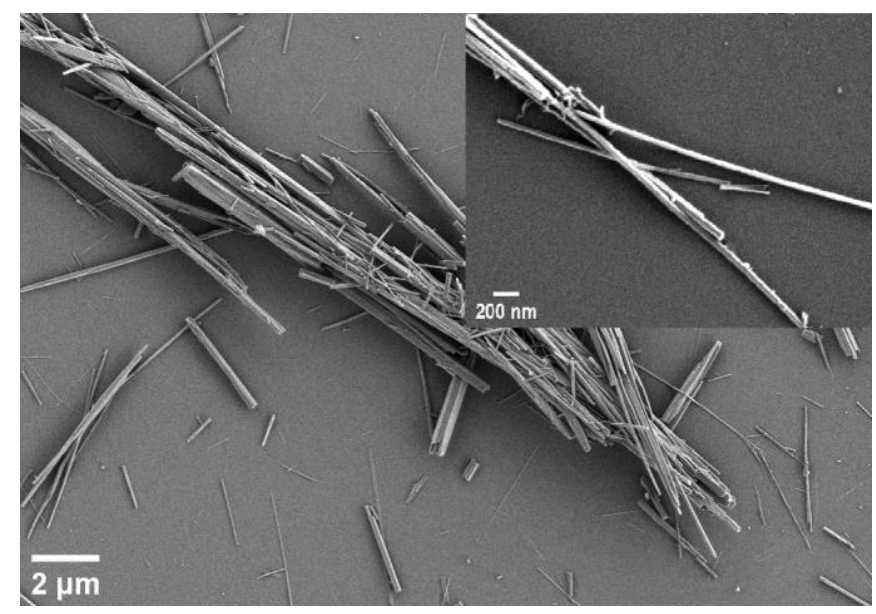

Figure 1. SEM images of CP. CP, polydisperse calcium phosphate nanowires.

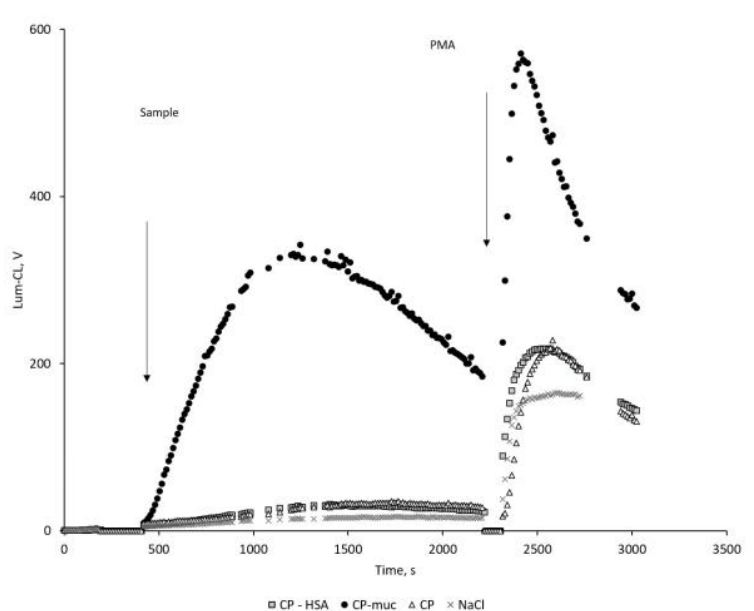

Figure 2. Time-course of neutrophil's Lum-CL stimulated with CP, CP-HSA, CP-Muc and $\mathrm{NaCl}$, and subsequent PMA addition. Lum-CL, luminoldependent chemiluminescence; $C P$, polydisperse calcium phosphate nanowires; $\mathrm{CP}-\mathrm{HAS}, \mathrm{CP}$ with sorbed human serum albumin; $\mathrm{CP}-\mathrm{M}, \mathrm{CP}$ with sorbed mucin; PMA, phorbol-12-myristate-13-acetate.

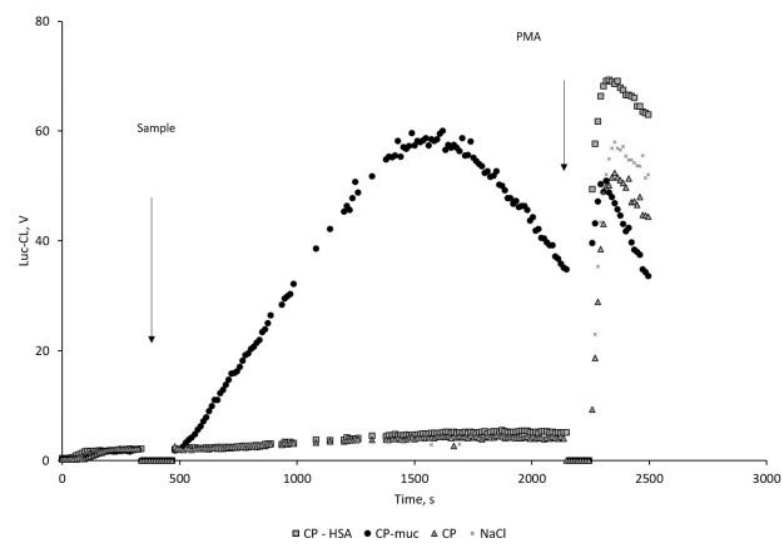

Figure 3. Time-course of neutrophil's Luc-CL stimulated with $\mathrm{CP}, \mathrm{CP}-\mathrm{HAS}$, CP-Muc and $\mathrm{NaCl}$, and subsequent PMA addition. Luc- $\mathrm{CL}$, lucigenindependent chemiluminescence; $C P$, polydisperse calcium phosphate nanowires; $\mathrm{CP}-\mathrm{HAS}, \mathrm{CP}$ with sorbed human serum albumin; $\mathrm{CP}-\mathrm{M}, \mathrm{CP}$ with sorbed mucin; PMA, phorbol-12-myristate-13-acetate. 


\section{Hemolytic activity assay}

$40 \mathrm{ul}$ of CP, CP-HSA or CP-Muc suspension $(10 \mathrm{mg} / \mathrm{mL})$ was mixed with $40 \mathrm{ul}$ of erythrocytes and $0.15 \mathrm{M} \mathrm{NaCl}$ was added so that final concentration of particles was $1.67 \mathrm{mg} / \mathrm{mL}$. The mixtures were incubated for $2 \mathrm{hr}$. at $37{ }^{\circ} \mathrm{C}$. The erythrocytes and particles were separated by centrifugation and supernatants were collected for further hemoglobin $(\mathrm{Hb})$ assay by absorbance at $540 \mathrm{~nm}$. The total hemolysis was induced by distilled $\mathrm{H}_{2} \mathrm{O}$; to assay spontaneous hemolysis $0.15 \mathrm{M} \mathrm{NaCl}$ was added to erythrocytes instead of particles. The results were expressed in \%: $\mathrm{HA}=(\mathrm{Hbx}-\mathrm{Hbsp}) /(\mathrm{Hbt}-$ $\mathrm{Hbsp}) \times 100 \%$, where HA-hemolytic activity (\%); Hbx, Hbt, Hbsp hemoglobin concentration $(\mathrm{mg} / \mathrm{mL})$ in supernatants of the probes with particles, $\mathrm{H}_{2} \mathrm{O}$ or $\mathrm{NaCl}$, correspondingly.
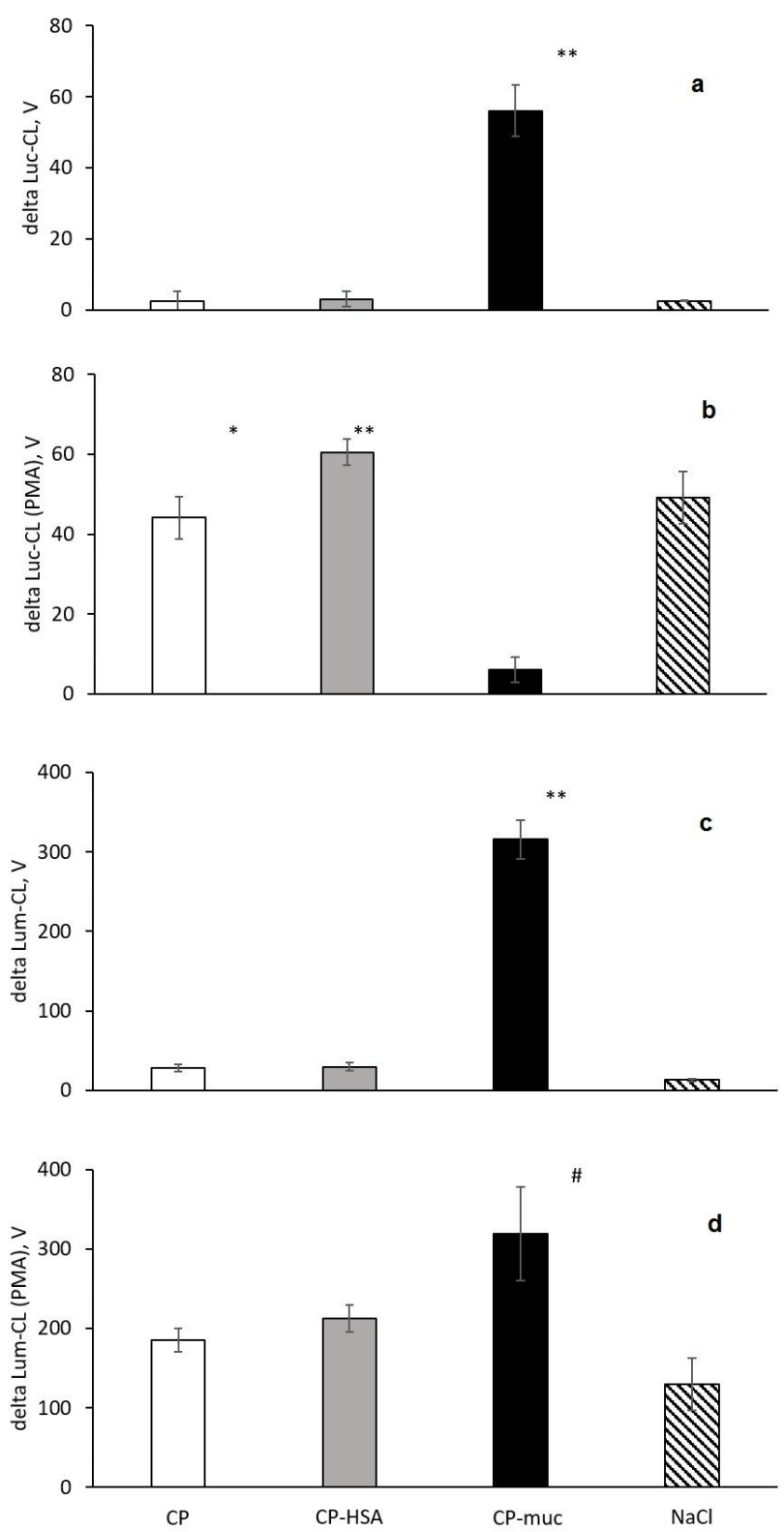

Figure 4. Amplitude of neutrophils' Luc-CL (a, b) and Lum-CL (c, d)response stimulated with $\mathrm{CP}, \mathrm{CP}-\mathrm{HSA}, \mathrm{CP}-\mathrm{Muc}$ and $\mathrm{NaCl}(\mathrm{a}, \mathrm{c})$ and to subsequent PMA addition (b, d).

** $p<0.001 ; * p=0.004 ; \# p=0.019$ vs. CP.

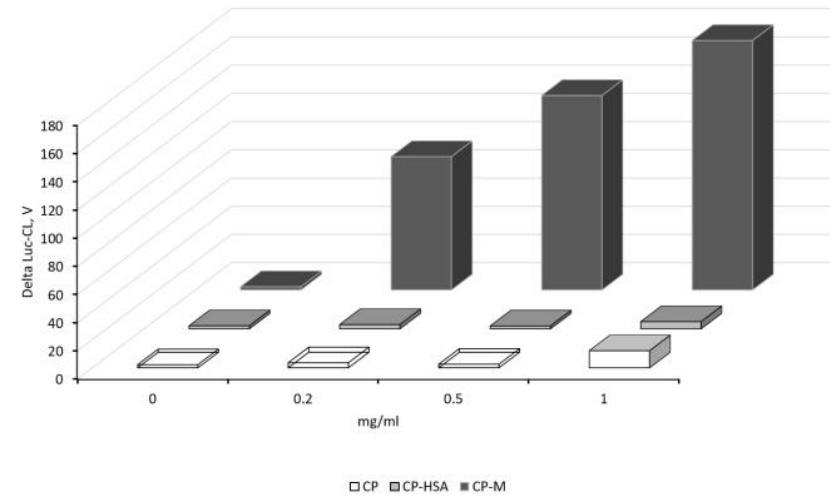

Figure 5. Amplitude of neutrophils' Luc-CL stimulated with CP, CP-HSA CP-M at various concentrations. Luc-CL, lucigenin-dependent chemiluminescence; $\mathrm{CP}$, polydisperse calcium phosphate nanowires; $\mathrm{CP}$ HAS, CP with sorbed human serum albumin; CP-M, CP with sorbed mucin.

\section{Chemiluminescent assay (CL)}

$\mathrm{CL}$ was measured with the use of luminometer Lum1200 (DiSoft, Moscow) in $0.5 \mathrm{~mL}$ of Krebs-Ringer solution ( $\mathrm{pH} 7.4)$ with $0.2 \mathrm{mM}$ luminol (Lum-CL) or lucigenin (LuC-CL), $2 \%$ of autologous blood serum, $0.5-0.7 \times 10^{6}$ neutrophils and $1 \mathrm{mg} / \mathrm{mL}$ particles. Spontaneous $\mathrm{CL}$ was measured before particles addition, then $\mathrm{CP}$, CP-HSA or CP-Muc was added and $\mathrm{CL}$ was registered until maximum values were reached; the $\mathrm{CL}$ amplitude (V) was calculated as difference between maximum and spontaneous values. If necessary, $100 \mathrm{ng} / \mathrm{mL}$ phorbol-12-myristate-13-acetate (PMA) as a second neutrophil activator was added after maximum was reached.

\section{Cytokine RNA expression}

Cytokine RNA was detected by means of reverse transcription with subsequent real-time $\mathrm{PCR}\left(\mathrm{RT}^{2} \mathrm{-PCR}\right)$ with fluorescent hydrolysis probes. Total nucleic acids were isolated from $50 \mu \mathrm{l}$ of control intact and experimental neutrophils after their treatment with $\mathrm{CP}, \mathrm{CP}-\mathrm{HSA}$ or $\mathrm{CP}-\mathrm{Muc}$ for $1 \mathrm{hr}$. at $37^{\circ} \mathrm{C}$, by using Proba-NK kit (DNA-technology, Russia). Then the reverse transcription was performed using Reverta-L kit (AmpliSens, Russia). RT2 ${ }^{2}$ PCR to detect mRNA of human interleukins with specific primers and probes was performed as previously described [15].

\section{Cytokine ELISA assay}

Neutrophils $\left(2 \times 10^{6}\right.$ cells $\left./ \mathrm{mL}\right)$ were incubated with CP, CP-HSA, CP-Muc $(1 \mathrm{mg} / \mathrm{mL})$ or with $0.15 \mathrm{M} \mathrm{NaCl}$ in Krebs-Ringer solution with $2 \%$ blood serum for $1 \mathrm{hr}$. at $37{ }^{\circ} \mathrm{C}$. Supernatants after centrifugation were collected and stored at $-60^{\circ} \mathrm{C}$ until analysis. Cytokines (IL-1 $\beta$, IL-6, IL-8, IL-10) were assayed with use of ELISA kits (OOO Cytokine, Russia) according to manufacturer instructions.

\section{Statistics}

Statistical significance levels were calculated with the Student's t-test using Statistics 12 (StatSoft). Data are represented as mean value \pm standard deviation. 
Table 1. RNA expression in neutrophils incubated with CP, CP-Muc and $\mathrm{NaCl}$ (delta Ct, \%)

\begin{tabular}{llll}
\hline & IL-6 & IL-8 & IL-10 \\
\hline $\mathrm{NaCl}$ & 100 & 100 & 100 \\
$\mathrm{CP}$ & 108 & 98 & 102 \\
$\mathrm{CP}-\mathrm{Muc}$ & 108 & 98 & 103 \\
\hline
\end{tabular}

$\mathrm{CP}$, polydisperse calcium phosphate nanowires; $\mathrm{CP}-\mathrm{Muc}, \mathrm{CP}$ with sorbed mucin.

Table 2. Concentration of interleukins in cell media after incubation of neutrophils with $\mathrm{CP}, \mathrm{CP}-\mathrm{M}$ and $\mathrm{NaCl}(\mathrm{pg} / \mathrm{mL})$

\begin{tabular}{lllll}
\hline & $\mathrm{IL}-1 \beta$ & $\mathrm{IL}-6$ & $\mathrm{IL}-8$ & $\mathrm{IL}-10$ \\
\hline $\mathrm{NaCl}$ & $1.6 \pm 0.1$ & $4.9 \pm 0.1$ & $22.8 \pm 2.8$ & $2.7 \pm 0.7$ \\
$\mathrm{CP}$ & 0 & $6.0 \pm 1.2$ & $18.6 \pm 4.4$ & $3.5 \pm 2.3$ \\
$\mathrm{CP}-\mathrm{Muc}$ & 0 & $4.0 \pm 1.7$ & $22.1 \pm 5.0$ & $1.8 \pm 0.8$ \\
\hline
\end{tabular}

$\mathrm{CP}$, polydisperse calcium phosphate nanowires; $\mathrm{CP}-\mathrm{Muc}, \mathrm{CP}$ with sorbed mucin.

\section{Results}

According to SEM images (Figure 1 ) CP had the length 1 to $10 \mu \mathrm{m}$ and thickness 50 to $450 \mathrm{~nm}$. Small fraction of nanorods with thickness of about $0.5 \mu \mathrm{m}$ was present, but each nanowire was a bundle of thinner nanowires with thickness of about $30 \mathrm{~nm}$. These particles adsorbed mucin in the range of $0.023 \pm 0.003 \mathrm{mg} / \mathrm{mg}$ and this sorption resulted in increase of net negative charge from $0.74 \pm 0.58 \mathrm{mV}$ to $-9.2 \pm 0.7 \mathrm{mV}$.

Hemolytic activity of the particles is considered as a measure of cell membrane damage so the study of CP bioactivity started with erythrocytes. $\mathrm{CP}$ hemolytic activity was $3.0 \pm 0.5 \%$ and protein sorption reduced it to spontaneous values: $0.24 \pm 0.04 \%$ for CP-Muc and $0.55 \pm 0.22 \%$ for $\mathrm{CP}-\mathrm{HSA}, \mathrm{p}<0.05$ vs. CP.

According to data of Lum-CL (Figure 2) and Luc-CL (Figure 3) measurement, CP-Muc activated neutrophils to significantly greater extent than CP or CP-HSA. Unbound mucin up to 0.5 $\mathrm{mg} / \mathrm{mL}$ induced no Luc-CL of neutrophils (data not shown).

Neutrophils' Cl-response was evaluated by amplitude, and data of independent experiments are summarized in Figure 4 (ad).

Neutrophil activation by CP-Muc resulted in $\mathrm{CL}$ amplitude increase but did not influence PMA-induced Lum- $\mathrm{CL}$ response which could mean that cells remain viable and active. Under the same conditions PMA-induced Luc-CL response after CP-Muc neutrophil stimulation was suppressed compared with responses after $\mathrm{CP}, \mathrm{CP}-\mathrm{HSA}$ and $\mathrm{NaCl}$. Since amplitude is represented as difference between maximum value at PMA stimulation and values before addition of PMA, lack of Luc- $\mathrm{Cl}$ values could be interpreted as exhaustion of NADPH-oxidase capacity for further increase of superoxide generation rate.

$\mathrm{CL}$ amplitude of neutrophils stimulated by particles depended on their concentration as shown for Luc-CL (Figure 5).

Neutrophil activation could result not only in respiratory burst but also in pro- and anti-inflammatory cytokine secretion. The expression level was determined by threshold cycle (Ct) delta (Table 1).

No significant difference between the samples was found. These results were confirmed by ELISA assay of interleukin secretion (Table 2)

\section{Discussion}

One of mucin functions is the protection of the mucosa and epithelium. Not only physical and chemical properties of mucins are important for its protective function but also its immunoregulatory role. Interaction of mucin with some bacteria can reduce inflammatory response via coating them and thus hindering further binding of complement proteins [16]. Sialic acids which are components of mucin oligosaccharide chains could interact with neutrophil receptors (Siglecs) known to dampen innate immune cell activation $[17,18]$. Airway mucins suppress the neutrophil oxidative burst through a charge dependent mechanism and bacterial killing [8]. Bound with membranes mucins regulate cell adhesion via lectin-carbohydrate interactions. Some oligosaccharide determinants of mucin such as sialylLe ${ }^{x}$ (NeuAca $2 \rightarrow 3$ Gal $\beta 1 \rightarrow 4[$ Fuc $\alpha 1 \rightarrow 3]$ GlcNac are recognized by neutrophil L-selectin [19].

Soluble mucins are easily sorbed by various surfaces [9] and calcium phosphate [5] or calcium carbonate particles [20] changing their properties. The effects of mucin coating on innate immune functions are still to be studied. Activation of neutrophil respiratory burst is one of the key reactions which characterize bioavailability of the foreign or endogenous particles and their proinflammatory properties. Calcium phosphate nanowires (CP) studied in the present work demonstrated high polydispersity and effects of their size and geometry remains to be investigated [21]. The commercial mucin from pig's stomach was used, with a surface charge of $-15 \pm 2 \mathrm{mV}$ and hydrodynamic diameter of 30-300 $\mathrm{nm}$ [14]. Mucin sorption increased net negative charge of CP which is consistent with data of other authors [5]. Hemolytic activity of $\mathrm{CP}$ was no more than $3 \%$ and mucin or HSA sorption gave additional protective effect towards erythrocytes. Unexpected enhancement of Lum-CL and Luc-Cl by CP-Muc unlike CP or CP-HSA could be explained by mechanism based rather on conformational effects than specific receptor binding. Mucin deposition on the particles facilitated multiple and cooperative interaction between its oligosaccharide determinants and neutrophil lectins, including L-selectin [22, 23], in the presence of calcium ions of CP. Probably, at least some part of the nanowires was bacterial-sized in length or thickness and that could favor neutrophil lectin clustering. No cytokine RNA expression or cytokine secretion was registered, and earlier the same was shown for dendritic cells activated by mucin, with except for IL-8 [24]. Even though the exact mechanism of the neutrophil activation with mucin-coated $\mathrm{CP}$ is unclear yet, its pathogenetic role is highly probable. The precipitation of mucin with calcium and phosphate ions stimulates cholesterol crystallization while activation of neutrophils by such particles induces further mucin production and inflammation $[6,7]$.

\section{Conclusion}

Our results have shown significant proinflammatory reaction of neutrophils towards CP coated with mucin and also gave a new perspective in analysis of proteins bioactivity.

\section{Conflict of interest}

The authors have no conflicts of interest to declare

\section{Funding}

Investigation of bioactivity of the particles using erythrocytes and neutrophils was supported by Russian Science Foundation grant № 201500390; evaluation of mucin binding and z-potential was carried out with 
financial support of the Public Procurement AAAA-A21-121011290089-4 with use of devices purchased according to Development Program of Lomonosov Moscow State University.

\section{Ethical approval}

All procedures performed in studies involving human participants were in accordance with the ethical standards of the institutional and/or national research committee and with the 1964 Helsinki declaration and its later amendments or comparable ethical standards.

\section{References}

1. Powell JJ, Thoree V, Pele LC. Dietary microparticles and their impact on tolerance and immune responsiveness of the gastrointestinal tract. $\mathrm{Br}$ $\begin{array}{llll}J & \text { Nutr 2007; } & \text { 98(suppl } & \text { 1): }\end{array}$ https://doi.org/10.1017/s0007114507832922.

2. Gelli R, Martini F, Geppi M, Borsacchi S, Ridi F, Baglioni P. Exploring the interplay of mucin with biologically-relevant amorphous magnesiumcalcium phosphate nanoparticles. J Colloid Interface Sci 2021; 594 : 802-811. https://doi.org/10.1016/j.jcis.2021.03.062.

3. Mashina EV, Shanina SN. Amino acid composition of gallstones and its connection with the mineral component. Proceedings of the Russian Mineralogical Society 148(4): 95-109. Russian. https://doi.org/10.30695/zrmo/2019.1484.07.

4. Van den Berg AA, Van Buul JD, Tytgat GNJ, Groen AK, Ostrow JD. Mucins and calcium phosphate precipitates additively stimulate cholesterol crystallization. J Lipid Res 1998; 39(9): 1744-1751. https://pubmed.ncbi.nlm.nih.gov/9741686.

5. Lori JA, Kazaure SZ, Dangogo SM. Mechanism for adsorption of mucin on hydroxyapatite. Nigerian Journal of Chemical Research 2005; 10 : 21-29.

https://www.ajol.info/index.php/njcr/article/download/35623/25223.

6. Muñoz LE, Boeltz S, Bilyy R, Schauer C, Mahajan A, Widulin N, et al. Neutrophil extracellular traps initiate gallstone formation. Immunity 2019; 51(3): 443-450. https://doi.org/10.1016/j.immuni.2019.07.002.

7. Burt HM, Jackson JK, Taylor DR, Crowther RS. Activation of human neutrophils by calcium carbonate polymorphs. Dig Dis Sci 1997; 42(6): 1283-1289. https://doi.org/10.1023/a:1018870511257.

8. Cantin AM, Ouellet C, Alexandre Cloutier A, McDonald PP. Airway mucins inhibit oxidative and non-oxidative bacterial killing by human neutrophils. Front Pharmacol 2020; 11: 554353. https://doi.org/10.3389/fphar.2020.554353.

9. Sandberg T, Carlsson J, Karlsson Ott M. Interactions between human neutrophils and mucin-coated surfaces. J Mater Sci Mater Med 2008; 20(2): 621-631. https://doi.org/10.1007/s10856-008-3595-y.

10. Grisham MB, Von Ritter C, Smith BF, Lamont JT, Ganger DN. Interaction between oxygen radicals and gastric mucin. Am J Physiol 1987; $253(1 \quad$ Pt $\quad 1): \quad$ G93-G96. https://doi.org/10.1152/ajpgi.1987.253.1.g93.

11. Memar MY, Adibkia K, Farajnia S, Kafil HS, Maleki-Diza S., Ghotaslou R. Biocompatibility, cytotoxicity and antimicrobial effects of gentamicinloaded $\mathrm{CaCO} 3$ as a drug delivery to osteomyelitis. Journal of Drug Delivery Science and Technology 2019; 54: 101307. https://doi.org/10.1016/j.jddst.2019.101307.

12. Posiedelik M, Markowicz-Piasecka M, Sikora J. Erythrocytes as model cells for biocompatibility assessment, cytotoxicity screening of xenobiotics and drug delivery. Chem Biol Interact 2020; 332: 109305. https://doi.org/10.1016/j.cbi.2020.109305ю

13. Zhan J, Tseng YH, Chan JCC, Mou CY. Biomimetic formation of hydroxyapatite nanorods by a single-crystal-to-single-crystal transformation. Advanced Functional Materials 2005; 15(12): 20052010 https://doi.org/10.1002/adfm.200500274

14. Balabushevich NG, Sholina EA, Mikhalchik EV, Filatova LY, Vikulina AS, Volodkin D. Self-assembled mucin-containing microcarriers via hard templating on $\mathrm{CaCO}_{3}$ crystals. Micromachines (Basel) 2018; 9(6): 307. https://doi.org/10.3390/mi9060307.

15. Morozova OV, Sokolova Al, Pavlova ER, Isaeva El, Obraztsova EA, Ivleva $E A$, et al. Protein nanoparticles: cellular uptake, intracellular distribution, biodegradation and induction of cytokine gene expression. Nanomedicine 2020; 102293. https://doi.org/10.1016/j.nano.2020.102293.

16. Mikhalchik E, Balabushevich N, Vakhrusheva T, Sokolov A, Baykova J, Rakitina D, et al. Mucin adsorbed by E. coli can affect neutrophil activation in vitro. FEBS Open Bio 2020; 10(2): 180-196. https://doi.org/10.1002/2211-5463.12770.

17. Lizcano A, Secundino I, Döhrmann S, Corriden S, Rohena C, Diaz S, et al. Erythrocyte sialoglycoproteins engage Siglec-9 on neutrophils to suppress activation. Blood 2017; 129(23): 3100-3110. https://doi.org/10.1182/blood-2016-11-751636.

18. Bornhöfft KF, Rebl A, Gallagher ME, Viergutz T, Zlatina K, Reid C, et al. Sialylated cervical mucins inhibit the activation of neutrophils to form neutrophil extracellular traps in bovine in vitro model. Front Immunol 2019; 10: 2478. https://doi.org/10.3389/fimmu.2019.02478.

19. Prakobphol A, Tangemann K, Rosen SD, Hoover $\mathrm{Cl}$, Leffler $\mathrm{H}$, Fisher SJ. Separate oligosaccharide determinants mediate interactions of the low-molecular-weight salivary mucin with neutrophils and bacteria. Biochemistry 1999; 38(21): 6817-6825. https://doi.org/10.1021/bi990145m.

20. Balabushevich NG, Kovalenko EA, Mikhalchik EV, Filatova LY, Volodkin $D$, Vikulina AS. Mucin adsorption on vaterite $\mathrm{CaCO}_{3}$ microcrystals for the prediction of mucoadhesive properties. J Colloid Interface Sci 2019; 545: 330-339. https://doi.org/10.1016/i.jcis.2019.03.042.

21. Parakhonsky B, Zyuzin MV, Yashchenok A, Carregal-Romero S, Rejman $\mathrm{J}$, Möhwald $\mathrm{H}$, et al. The influence of the size and aspect ratio of anisotropic, porous $\mathrm{CaCO}_{3}$ particles on their uptake by cells. J Nanobiotechnology 2015; 13: 53. https://doi.org/10.1186/s12951-0150111-7.

22. Crottet P, Kim YJ, Varki A. Subsets of sialated, sulfated mucins of diverse origins are recognized by L-selectin. Lack of evidence for unique oligosaccharide sequences mediating binding. Glycobiology 1996; 6(2): 191-208. https://doi.org/10.1093/glycob/6.2.191.

23. Dwir O, Steerber DA, Schwarz US, Camphausen RT, Kansas GS, Tedder $\mathrm{TF}$, et al. L-selectin dimerization enhances tether formation to properly spaced ligand. J Biol Chem 2002; 277(24): 21130-21139. https://doi.org/10.1074/jbc.m201999200.

24. Melo-Gonzalez F, Fenton TM, Forss C, Smedley C, Goenka A, MacDonald AS, et al. Intestinal mucin activates human dendritic cells and IL-8 production in a glycan-specific manner. J Biol Chem 2018; 293(22): 8543-8553. https://doi.org/10.1074/ibc.m117.789305.

\section{Authors:}

Elena V. Mikhalchik - DSc, Lead Researcher, Laboratory of Physicochemical Research Methods and Analysis, Federal Research Clinical Center of Physicochemical Medicine, Moscow, Russia. https://orcid.org/0000-00026431-125X.

Olga P. Boychenko - Lab Assistant, Laboratory of Medical Biotechnology, Federal Research Clinical Center of Physicochemical Medicine, Moscow, Russia; Student, Lomonosov Moscow State University, Moscow, Russia. https://orcid.org/0000-0001-6246-7085.

Alexander P. Moskalets - PhD, Researcher, Laboratory of Medical Biotechnology, Federal Research Clinical Center of Physicochemical Medicine, Moscow, Russia. https://orcid.org/0000-0002-7202-0268.

Olga V. Morozova - DSc, Lead Researcher, Laboratory of Medical Biotechnology, Federal Research Clinical Center of Physicochemical Medicine, Moscow, Russia; National Research Center of Epidemiology and Microbiology of N.F. Gamaleya, Moscow, Russia. https://orcid.org/00000001-9630-0777.

Dmitry V. Klinov - PhD, Researcher, Laboratory of Medical Biotechnology, Federal Research Clinical Center of Physicochemical Medicine, Moscow, Russia. https://orcid.org/0000-0001-8288-2198. 
Liliya Yu. Basyreva - PhD, Senior Researcher, Laboratory of Physicochemical Research Methods and Analysis, Federal Research Clinical Center of Physicochemical Medicine, Moscow, Russia. https://orcid.org/0000-0002-5170-9824.

Sergey A. Gusev - DSc, Principal Researcher, Laboratory of Physicochemical Research Methods and Analysis, Federal Research Clinical Center of Physicochemical Medicine, Moscow, Russia. https://orcid.org/0000-0003-0383-2649.

Oleg M. Panasenko - DSc, Professor, Chair of the Laboratory of Physicochemical Research Methods and Analysis, Federal Research Clinical Center of Physicochemical Medicine, Moscow, Russia. https://orcid.org/0000-0001-5245-2285.

Lyubov Yu Filatova - PhD, Researcher, Department of Chemical Enzymology, School of Chemistry, Lomonosov Moscow State University, Moscow, Russia. https://orcid.org/0000-0002-3123-1341.

Nadezhda G. Balabushevich - PhD, Associate Professor, Senior Researcher, Department of Chemical Enzymology, School of Chemistry, Lomonosov Moscow State University, Moscow, Russia. https://orcid.org/0000-00028465-0400. 